\title{
PRIMEIRO REGISTRO DE OCORRÊNCIA DO PARASITÓIDE Brasema sp. (HYMENOPTERA: EUPELMIDAE) EM OVOS DE Leptoglossus zonatus (DALLAS, 1852) (HEMIPTERA: COREIDAE) NO BRASIL ${ }^{1}$
}

\author{
FIRST RECORD OF OCCURRENCE OF THE PARASITOID Brasema sp. \\ (HYMENOPTERA: EUPELMIDAE) IN EGGS OF Leptoglossus zonatus \\ (DALLAS, 1852) (HEMIPTERA: COREIDAE) IN BRAZIL
}

\author{
Carlos Henrique Marchiori ${ }^{2}$ Aldaisa Martins da Silva Oliveira ${ }^{3}$ \\ Márcio Cleiber Rabelo Costa ${ }^{4}$
}

\begin{abstract}
Este trabalho registra a primeira ocorrência do parasitóide Brasema sp. (Hymenoptera: Eupelmidae) parasitando ovos de Leptoglossus zonatus (Hemiptera: Coreidae) em cultivar de milho em Itumbiara, GO. A porcentagem de parasitismo foi de 4,8\%. Brasema sp. constituese em ectoparasitóide de larvas de coleópteros e de outros hospedeiros no interior de tecidos de plantas.
\end{abstract}

Palavras-chave: ocorrência, inimigo natural, controle biológico, parasitóide.

\section{SUMMARY}

This work reports, for the first time, of parasitoid Brasema sp. (Hymenoptera: Eupelmidae) parasitizinf eggs of Leptoglossus zonatus (Hemiptera: Coreidae) in maize cultivate in Itumbiara, GO, Brazil. The percentage of parasitizing was $4,8 \%$. Brasema sp. constitutes ectoparasitoid of beetle larvae and other hosts concealed in plant tissue.

Key words: occurrence, natural enemie, biological control parasitoid.
$\mathrm{O}$ uso de agentes biológicos para o controle de pragas tem se intensificado nos últimos anos no Brasil, com resultados significativos no manejo desses organismos fitófagos. Há grande interesse na adoção de medidas biológicas para o controle de pragas, devido ao efeito danoso dos inseticidas químicos ao ambiente, uma vez que pode contaminar os alimentos e prejudicar a vida silvestre. Esse método de controle faz-se principalmente por predadores e parasitóides (CRUZ \& OLIVEIRA, 1997; CRUZ et al., 1997; SILVA et al., 1997).

O hábito parasitóide dos Chalcidoidea predomina entre suas espécies, muitas das quais têm sido utilizadas com sucesso em programas de controle biológico (PERIOTO \& TAVARES, 1999). A grande diversidade desse grupo de insetos pode ser avaliada pela gama de hospedeiros que podem atacar e, que se distribuem nas seguintes ordens de insetos: Coleoptera, Diptera, Hemiptera, Homoptera, Hymenoptera, Lepidoptera, Neuroptera, Odonata, Orthoptera, Siphonaptera e outros (GRISSELL \&

\footnotetext{
${ }^{1}$ Financiado por: $\mathrm{CNPq}$.

${ }^{2}$ Biólogo, Doutor, Professor Titular, Departamento de Ciências Naturais do Instituto Luterano de Ensino Superior de Itumbiara (ILES),

Universidade Luterana do Brasil (ULBRA). Av.: Beira Rio, 1001, Bairro Nova Aurora, 75500-000, Itumbiara, GO. Fax: (64)431-8239.

E-mail: pesquisa.itb@ulbra.br. Autor para correspondência.

${ }^{3}$ Engenheiro Agrônomo, Mestrando, Professor Adjunto, Departamento de Ciências Naturais do ILES, ULBRA. Bolsista CNPq

${ }^{4}$ Aluno do Curso de Graduação em Agronomia, ILES, ULBRA. Bolsista CNPq.
} 
SCHAUFF, 1990), além de ácaros, aracnídeos e nemátodos.

A família Eupelmidae apresenta maior diversidade na região Neotropical e é composta por três subfamílias, sendo que algumas espécies de Eupelminae, especialmente aquelas que atacam ovos de insetos, desenvolvem-se como endoparasitóides idibiontes. Várias espécies têm sido utilizadas em programas de controle biológico (GRISSELL \& SCHAUFF, 1990; PERIOTO \& TAVARES, 1999). O gênero Brasema pertence a essa sub-família, constitui-se em ectoparasitóide de larvas de coleópteros e de outros hospedeiros no interior de tecidos de plantas (HANSON \& GAULD, 1995).

Leptoglossus zonatus (DALLAS, 1852)

(Hemiptera: Coreidae), um hemíptero de ocorrência comum nas culturas milho, sorgo, feijoeiro, soja, tomateiro e citros, suga os grãos e frutos provocando murchamento, apodrecimento e conseqüentemente queda na produção. No milho, os prejuízos podem chegar a 15\% (ZUCCHI et al., 1993).

O objetivo deste trabalho foi fazer o levantamento de parasitóides em ovos de hemípteros na cultura do milho.

$\mathrm{O}$ experimento foi realizado na fazenda Santa Maria, município de Itumbiara (18²5'S e 49 $13^{\prime}$ 'W) Goiás, que possui 100 hectares destinados à plantação de soja, milho e à criação de bovinos leiteiros. As coletas se procederam em um hectare de milho (cultivar Dekalb 601), que foi dividido em 7 parcelas de 44x20m. Coletaram-se aleatoriamente, oito espigas de milho em cada parcela, perfazendose um total de 56 espigas, as quais foram individualizadas em sacos plásticos, levadas ao laboratório do Instituto Luterano de Ensino Superior para obtenção dos insetos.

Verificou-se a presença de ovos de Hemiptera (massa de ovos) em uma espiga de milho. Com a finalidade de obter parasitóides, essa massa foi colocada, junto a um pequeno pedaço da bainha foliar (para evitar possíveis perdas de material por danos mecânicos) em um frasco de vidro e mantidos no laboratório à temperatura ambiente até a emergência dos parasitóides e/ou de ninfas do inseto praga.

As coletas foram realizadas semanalmente, no período de 22 de janeiro a 23 de fevereiro de 2001. Os parasitóides foram identificados pelo Dr. Marcelo Teixeira Tavares, do
Centro Universitário de Araraquara, São Paulo e as ninfas de $L$. zonatus utilizando-se o trabalho de ZUCCHI et al. (1993). A porcentagem de parasitismo foi calculada pela fórmula: $\mathrm{P}=$ (ovos parasitados/total de ovos)x100.

Foi coletado um total de 41 ovos de $\boldsymbol{L}$. zonatus, dos quais eclodiram 30 ninfas e emergiram 9 parasitóides do gênero Gryon (Hymenoptera: Scelionidae) e dois do gênero Brasema (Hymenoptera: Eupelmidae). O parasitismo total foi de 26,8\%, sendo 4,8\% efetuada por Brasema $\mathbf{s p .}$

Esses resultados contribuem para $\mathrm{O}$ conhecimento dos parasitóides que ocorrem em Goiás. Por se tratar de um grupo de inimigos naturais de pragas agrícolas, verifica-se a possibilidade de sua utilização como agente de controle biológico na cultura do milho, neste Estado.

\section{REFERÊNCIAS BIBLIOGRÁFICAS}

CRUZ, I., OLIVEIRA, A.C. Flutuação populacional do predador Doru luteipes Scuder em plantas de milho. Pesquisa Agropecuária Brasileira, Brasília, DF, v.32, n.4, p.363-368, 1997.

CRUZ, I., FIGUEIREDO, M.L.C, GONÇALVES, E.P., et al. Efeito da idade de lagartas de Spodoptera frugiperda (Smith) (Lepidoptera: Noctuidae) no desempenho do parasitóide Campoletis flavicinta (Ashmead) (Hymenoptera: Ichneumonidae) e consumo foliar por lagartas parasitadas e não parasitadas. Anais da Sociedade Entomológica do Brasil, Londrina, PR, v.26, n.2, p.229-234, 1997.

GRISSELL, E.E., SCHAUFF, M.E. A handbook of the families of Nearctic Chalcidoidea (Hymenoptera). Washington : Entomological Society of Washington, 1990. 86p.

HANSON, P.E., GAULD, I.D. The Hymenoptera of Costa Rica. Oxford : University, 1995. 893p

PERIOTO, N.W., TAVARES, M.T. A Chalcidoidea. In: BRANDÃO, C.R.F, CANCELLO, E.M. Invertebrados terrestres. Vol. V. Biodiversidade do Estado de São Paulo. Síntese do conhecimento ao final do século XX. São Paulo : FAPESP, SP, 1999. Cap. 17. p. 153168 .

SILVA, F.M.A., FOWLER, H.G., LEMOS, R.N.S. Parasitismo em lagarta-do-cartucho, Spodoptera frugiperda (Smith), na Região do Triângulo Mineiro, MG. Anais da Sociedade Entomológica do Brasil, Londrina, PR, v.26, n.2, p. 235241, 1997.

ZUCCHI, R.A.; NETO, S.S., NAKANO, O. Guia de identificação de pragas agrícolas. Piracicaba : FEALQ, SP, 1993. 139p. 